descriptive text is correct for 1908. The draughtsmanship is not expert and the drawings should have been reduced from a larger size to conceal its defects. If a future generation is to learn its biology this way, it is to be hoped that the publishers will take their task more seriously and remedy these shortcomings.

\section{Acquisitions at the British Museum (Natural History)}

ReCent acquisitions by the Department of Zoology include a specimen of the frilled shark (Chlamydoselachus) caught by a trawler off the west of Ireland. This is the first occasion on which this species has occurred in British waters. It was first discovered off the Japanese coasts. The frilled shark is of great interest on account of the many primitive characters which it possesses. The mouth is at the end of the snout, instead of being underhung as in most living sharks. There are six gill openings on each side instead of the usual five, and the teeth are of a curious comb-like shape. The body is much more slender and eel-like than in other sharks, and in several ways it approaches some of the very ancient types of fossil shark-like fishes. Through the generosity of the trustees of the Salisbury, South Wilts and Blackmore Museum, the Department of Geology has received a large number of fossil invertebrates and fishes, forming part of the collection made by the late Dr. H. P. Blackmore from the Chalk in the vicinity of Salisbury. A further valuable instalment of 488 specimens of Swiss minerals, representing 59 carefully recorded localities, collected by himself, has been presented by Mr. F. N. Ashcroft to the Department of Minerals.

THE Department of Botany has received a bequest of Mr. T. J. Foggitt's British herbarium. This numbers 4640 sheets of well-gathered and beautifully preserved plants. Mr. Foggitt was a well-known Yorkshire botanist, the son of the T. J. Foggitt who collaborated with J. G. Baker in the formation of the Botanical Exchange Club which brought Thirsk into botanical prominence in the sixties of last century. The herbarium is rich in Yorkshire plants, and is a welcome addition not only for this but also on account of the large number of extremely rare plants it contains. The Siamese collection of Dr. A. Marcan has been purchased. It contains abundant material of 2772 numbers including several co-types. It has been named for the most part by the late Prof. W. Craib and Dr. A. Kerr. The collection forms a valuable addition to the Department which is weak in Siamese plants. A further set of Dr. H. Schlieben's Tanganyika plants numbering 146 has been purchased. The first two fascicles of Lundell and Nannfeldt's "Fungi exsiccati suecici praesertim Upsalienses" has been presented by the Elias Fries Committee. This exsiccata is of especial interest as it consists mainly of fungi collected in the neighbourhood of Uppsala, a region made famous by the classical works of Elias Fries.

\section{Rural Electrification in Russia}

ONE of the results of the first five-year plan is to change fundamentally the character of farm work in the U.S.S.R. Instead of a million small holdings, there are now only some thousands of large collective agricultural and pastoral farms. Horse traction and manual labour are rapidly being replaced by the mechanical tractor and electrically driven machines and implements. Electrification is the key-note of the industrial reorganisation of the country. In the Electrical Review of February 22, G. Shapiro gives a description of some of the new agricultural and dairy farming methods. Experiments on electrical haulage and electric tractors for ploughing have proved most satisfactory. The electric tractors used for ploughing were usually converted mechanical tractors in which the internal combustion engines had been replaced by electric motors. The results show a considerable saving in working expenses. Excellent results are being obtained with electric threshing, which is developing very rapidly. These machines are produced in Kharkov, and are driven by electric motors. Electrically driven machines have also been successfully experimented on in connexion with vineyards, tea plantations and cotton fields. In dairy farms, electricity will be used for milking, cleaning the animals, preparing food, water pumping, ventilation, butter making, cheese making and lighting. Pig farms and poultry farms also take an appreciable electric load. Researches are being made on the heating of the soil and the influence of light and various rays on seeds, roots and poultry and animal breeding. By the end of the second five year plan (1937), it is anticipated that about 30,000 stations will be threshing electrically and will cover a sowing area of about 30 million acres.

\section{Aerodrome Lighting for Night Flying}

OwING to the steady increase in the number of passengers and in the volume of the mails carried by aeroplanes, the proper lighting of aerodromes has become of great importance. In the G.E.C. Journal of November, Mr. W. A. Villiers describes the equipment produced by the General Electric Company for this purpose. The problem is to give the pilot of an aeroplane flying on a dark night the guidance he requires to make a safe landing. In many cases at the present time, aerodromes are only a few miles apart; he must therefore be able to identify the place with certainty. This is done by means of a beacon. The light must be visible in all weathers, but must not be dazzling. The colour and character of the light should be different from that given by neighbouring beacons. The beacon is in the shape of a truncated cone about $14 \mathrm{ft}$. high, formed of six hairpin-shaped neon tubes giving the usual red neon colour. It has low intrinsic brilliancy, but in favour. able weather conditions can be seen at a distance of 50 miles. The identification is usually effected by making it flash in Morse characters the initial letter of the aerodrome. The boundary of the landing place is marked out by electric lamps inside orange glass globes. All landings are made against the wind as this direction gives the safest landing. The landing ground should always be flood-lighted, the space being so large that even the fastest aeroplane does not overrun the lighted area. Nine Osram lamps 
each taking a kilowatt are used for this purpose. Views are shown of the flood-lighting employed at Croydon air-port.

\section{American Amaryllis Society}

THE first year book (1934) of this Society has recently been published under the editorship of Dr. Hamilton P. Traub (Orlando, Florida ; 2 dollars). Plants belonging to the genera Amaryllis, Hippeastrum, Crinum, Zephyranthes, Alstromeria and others are the special objects of the Society, though its interest can reasonably be expected to include such well-known plants as snowdrops, daffodils and snowflake (Leucojum). A useful classification for show purposes has been prepared, and the Fischer colour chart has been adopted as the standard of colour nomenclature. Botanical descriptions of the Amarylideæ according to Baker are given, and many pages are devoted to the breeding of the various species. Other sections deal with propagation and culture, whilst insect pests and diseases receive brief mention. Storage, forcing and marketing are also discussed. One of the most noticeable features is the brevity of each contribution, for nearly seventy articles are included in the 102 pages of the volume. The memory of Henry Nehrling, a noted raiser of Amaryllis plants, is honoured by dedication of the first year book.

\section{The Observatories Year Book 1932}

ThIs important publication of the British Meteorological Office (Air Ministry) contains a very large mass of meteorological and geophysical information, obtained at the five observatories of Lerwick, Aberdeen, Eskdalemuir, Valencia and Kew, together with upper-air observations made by sounding balloons (London: H,M. Stationery Office.) Its appearance has been slightly delayed owing to a change in its mode of production: hitherto it has been printed, but in the present issue most of the extensive tabular matter, and part of the text, is reproduced direct from typescript by the Replika process of Messrs. Percy Lund, Humphries and Co., Ltd. There is a certain loss in legibility and appearance, but this disadvantage is on the whole outweighed by the reduction in cost thus achieved; the reduction is passed on to the purchaser, since the "Year Book" now costs two guineas (postage extra) instead of three as for the preceding volumes. The volume provides a very important record of the meteorological and magnetic conditions over the British Isles during 1932.

\section{American Expedition to Tibet}

AN expedition of the Academy of Natural Sciences of Philadelphia has recently left Yachow in Szechwan Province, China, for a year's survey of the zoology of eastern Tibet. The party is under the leadership of Brooke Dolan of Philadelphia who, with some of his staff, has had previous experience in the western China area. Its main object is to obtain information and material for habitat groups of typical Tibetan animals, such as the wild yak, wild horse, ammon sheep, snow leopard, Tibetan gazelle and bear; and as an aid to this end motion pictures will be taken of the wild game, which is said to be abundant on the high steppes of Kuku-nor and Tsaidam. Mr. Dolan's party is working in co-operation with the Metropolitan Museum of the Academia Sinica in Nanking. It is gratifying to find that expeditions in out of the way parts of the world are concentrating more upon observation of animal distribution and habits than upon the unrestrained collecting which was often divorced from any sort of ecological observation.

\section{Age of a Stone Curlew}

A short note (Proc. Roy. Zool. Soc. N.S. Wales, 1933-34) records the presence in a suburb of Sydney of a fine specimen of stone curlew, which has attained a great age for such a bird. He was brought to Sydney in his third year, and by the end of 1934 he will have passed his twenty-ninth birthday; during all the time he has been allowed absolute freedom in the garden. More information regarding this interesting bird would have been welcome. On what has it been fed during these years, for the food of waders is not always easy to obtain ? Also, has it ever shown any movements suggestive of a desire to migrate at the proper season?

\section{International Inquiry into Television}

THE Rome correspondent of The Times states that the executive committee of the Institute of Educational Cinematography has decided to set up an international committee to study the problems raised by television. The committee, which will be composed of representatives of national organisations in Europe and America interested in television, will inquire into the condition of television in the various countries and the questions raised by its practical utilisation; the relations between television and cinematography; and the use of television for cultural and educational purposes.

\section{Scientific Research in Japan}

THE report of the National Research Council of Japan for the year ending March 1933 shows that, during the year, meetings of the following divisions of the Council were held: administration, astronomy, geophysics, chemistry, physics, geology and geography, agriculture, medical sciences, engineering and mathematics. Each division has sectional committees which deal with branches of the work, as for example, dyestuffs, industrial research and radio research; and delegates attended the meetings of the International Unions of Astronomy at Cambridge, Mass., and of Mathematics at Zurich. The urgent necessity of encouraging and supporting scientific and industrial research has led to the formation of a "Foundation for the Promotion of Scientific and Industrial Research of Japan" which was incorporated in December 1932 with an annual Government grant of 700,000 yen for current expenses. 